AL-URBAN: Jurnal Ekonomi Syariah dan Filantropi Islam

Vol. 1, No. 1, Juni 2017

http://journal.uhamka.ac.id/index.php/al-urban

p-ISSN: 2580-3360 e-ISSN: 2581-2874

DOI: $10.22236 /$ alurban_vol1/is1pp15-25

Hal 15-25

\title{
TINGKAT BAGI HASIL, PERTUMBUHAN LIKUIDITAS, DAN PRODUK DOMESTIK BRUTOTERHADAP SIMPANAN MUDHARABAH
}

\author{
Ismayana Marhamah
}

Studi Ekonomi Syariah Institute

Email: ismayanamarhamah@gmail.com

Diterima: 3 Mei 2017; Direvisi: 7 Mei 2017; Disetujui: 25 Mei 2017

\begin{abstract}
This study aims to determine the effect of profit sharing growth, liquidity growth, gross domestic product (GDP) growth, of mudharabah saving growth in general islamic banks. The variables studied are the influence of profit sharing rate, liquidity growth, gross domestic product (GDP) growth as independent variable and mudharabah saving growth as dependent variable. The population in this study are sharia islamic banks registered in Bank Indonesia (BI) and the amount of gross domestic productquarter-year period 2012-2016.The result of hypothesis testing ( $t$ test) shows that the profit sharing growth and gross domestic product partially has significant effect to mudharabah saving growth. Then the test result of liquidity growth partially has no effect and not significant to mudharabah saving growth. The results of simultaneous hypothesis test (test F), show that all independent variabels in this study has significant effect to mudharabah saving growth.
\end{abstract}

Keywords:Profit Sharing, Liquidity, Gross Domestic Product,Mudharabah

\begin{abstract}
Abstrak
Penelitian ini bertujuan untuk mengetahui pengaruh pertumbuhan tingkat bagi hasil, pertumbuhan likuiditas, dan pertumbuhan produk domestik bruto (PDB) terhadappertumbuhan simpanan mudharabah pada bank umum syariah. Variabel yang diteliti adalah pertumbuhan tingkat bagi hasil, pertumbuhan likuiditas, pertumbuhan produk domestik bruto (PDB)sebagai variabel independen dan pertumbuhan simpanan mudharabah sebagai variabel dependen. Populasi dalam penelitian adalah bank umum syariah dan jumlah produk domestik bruto periode triwulan tahun 2012-2016.Pengujian hipotesis (uji t), menunjukkan bahwa pertumbuhan tingkat bagi hasil dan produk domestik bruto (PDB) secara parsial berpengaruh signifikan terhadap pertumbuhan simpanan mudharabah. Sedangkan pengujian pertumbuhan likuiditas secara parsial tidak berpengaruh dan tidak signifikan terhadap pertumbuhan simpanan mudharabah. Uji hipotesis secara simultan (uji F) menunjukkan bahwa semua variabel bebas dalam penelitian ini berpengaruh signifikan terhadap pertumbuhan simpanan mudharabah.
\end{abstract}

Kata Kunci:Tingkat Bagi Hasil,Likuiditas, Produk Domestik Bruto, Mudharabah 


\section{PENDAHULUAN}

Indonesia merupakan negara yang mayoritas penduduknya muslim. Dewasa ini, mereka menyadari bahwa penerapan hukum Islam harus menyeluruh diterapkan dalam semua sektor kehidupan, termasuk di dalamnya perekonomian. Sistem perekonomian yang diinginkan oleh sebagian besar masyarakat muslim di Indonesia adalah berbasis syariah (berlandaskan Al-Qur'an dan As-Sunnah). Oleh karena itu, Majelis Ulama Indonesia (MUI) sebagai pembimbing dan pelayan umat (ra'iy wa khadim al ummah) mengupayakan adanya perekonomian yang sesuai dengan prinsip Islam yaitu perbankan syariah yang sekarang marak keberadaanya. Bahkan, bank konvensional pun sekarang menyediakan basis syariahnya.

Dalam menjalankan usaha keuangannya, bank syariah memerlukan sumber dana yang cukup. Salah satu sumber dana yang dimiliki oleh bank syariah adalah dana yang berasal dari masyarakat atau yang disebut dengan Dana Pihak Ketiga (DPK).

Sebagian besar kegiatan operasional bank syariah khususnya dalam menyalurkan pembiayaan, bergantung pada besarnya DPK yang mampu dihimpun oleh bank syariah. Jika dana DPK yang dihimpun oleh bank syariah semakin meningkat, maka bank syariah memiliki kesempatan yang besar untuk meningkatkan jumlah pembiayaan yang disalurkannya kepada masyarakat.

Diantara produk-produk DPK bank syariah itu, deposito mudharabah merupakan produk penghimpunan dana yang memberikan proporsi terbesar terhadap total DPK bank syariah. Deposito mudharabah merupakan produk investasi tidak terikat pihak ketiga pada bank syariah yang penarikannya hanya dapat dilakukan pada waktu tertentu dengan pembagian usaha sesuai nisbah yang disepakati diawal pembukaan rekening.

Mudharabah adalah akad kerjasama usaha antara 2 (dua) pihak, di mana pihak pertama bertindak sebagai pemilik dana (shaibul mal) yang menyediakan seluruh modal (100\%), sedangkan pihak lainnya sebagai pengelola usaha (mudharib) (Dimyauddin Djuwaini, 2008).

Deposito pada bank syariah dengan prinsip mudharabah menggunakan sistem bagi hasil dalam pembagian keuntungan kepada nasabah, sehingga jumlah keuntungan yang didapat tidak selalu sama atau selalu berfluktuasi sesuai 
17AL-URBAN: Jurnal Ekonomi Syariah dan Filantropi Islam

Vol. 1, No. 1, Juni 2017

http://journal.uhamka.ac.id/index.php/al-urban

p-ISSN: 2580-3360 e-ISSN: 2581-2874

DOI: $10.22236 /$ alurban_vol1/is1pp15-26

Hal 15-25

tingkat pendapatan bank dan nisbah- kembali kepada masyarakat dalam bentuk nya.Nisbah bagi hasil merupakan pinjaman (kredit), serta memberikan jasapembagian atas hasil usaha yang telah jasa bank lainnya. Untuk bisa dilakukan oleh pihak-pihak yang menghimpun dana dari masyarakat, maka melakukan perjanjian yaitu pihak nasabah bank memiliki keharusan untuk dan pihak bank syariah. Dalam hal meyakinkan nasabah bahwa uang yang terdapat dua pihak yang melakukan mereka titipkan dijamin keamanannya. perjanjian usaha, maka hasil atas usaha Dengan demikian, agar bisa memberikan yang dilakukan oleh kedua pihak atas keamanan kepada para nasabah, maka salah satu pihak dibagi sesuai dengan bank tersebut haruslah likuid. Likuiditas porsi masing-masing pihak yang bank adalah kemampuan bank untuk melakukan akad perjanjian (Ismail, 2011). memenuhi kewajibannya, terutama

Ketika kondisi keuangan bank kewajiban dana jangka pendek (Khaerul mengalami keuntungan maka keuntungan Umam, 2013). Likuiditas bank diduga tersebut akan dibagikan kepada nasabah mempengaruhi pertumbuhan simpanan sesuai dengan akad yang telah disepakati mudharabah.

di awal, begitu pula sebaliknya ketika bank mengalami kerugian maka kerugian tersebut akan ditanggung bersama. Jadi pada dasarnya bank syariah lebih condong pada upaya untuk mendorong penerapan berbagi resiko. Dalam hal ini tingkat bagi hasil menjadi hal yang di pertimbangkan oleh nasabah dalam menyetorkan dananya, semakin tinggi tingkat bagi hasil maka akan semakin banyak nasabah yang ingin menyetorkan dananya.

Disisi lain, tugas utama bank adalah menghimpun dana dari masyarakat dalam bentuk simpanan. Kemudian dana yang telah terkumpul tersebut disalurkan

Bank wajib menyediakan likuiditas tersebut dengan cukup dan mengelolanya dengan baik karena apabila likuiditas tersebut terlalu kecil, akan mengganggu kegiatan operasional bank. Sekalipun demikian, likuiditas juga tidak boleh terlalu besar karena jumlah likuiditas yang terlalu besar akan menurunkan efisiensi bank sehingga berdampak pada rendahnya tingkat profitabilitas. Dalam hal bank tidak mampu memenuhi kebutuhan dana dengan segera untuk memenuhi kebutuhan transaksi sehari-hari ataupun memenuhi kebutuhan dana yang mendesak, muncullah risiko likuditas (Khaerul 
Umam, 2013). Faktor lain yang diduga mempengaruhi pertumbuhan simpanan mudharabah, faktor produk domestik bruto (PDB). Faktor PDB diperhitungkan untuk mewakili tingkat pendapatan atau kegiatan ekonomi. Hal ini berkaitan bahwa tingkat pendapatan menggambarkan kemampuan masyarakat untuk menabung, dalam teori Keynes semakin tinggi pendapatan, maka akan tinggi pertumbuhan simpanan mudharabah pada bank syariah.

\section{METODE PENELITIAN}

Dalam penelitian ini digunakan metode pendekatan eksplanasi (explanatory research), yaitu untuk menguji hubungan antar variabel yang dihipotesiskan. Penggunaan metode eksplanasi dalam penelitian ini bertujuan untuk mengetahui pengaruh variabel independen yaitu pertumbuhan tingkat bagi hasil, pertumbuhan likuditas, dan pertumbuhan produk domestik bruto terhadap variabel dependen yakni pertumbuhan simpanan mudharabah.

Variabel bebas yang akan berkaitan dengan masalah yang akan diteliti adalah variabel $\left(\mathrm{X}_{1}\right)$ pertumbuhan tingkat bagi hasil, $\left(\mathrm{X}_{2}\right)$ pertumbuhan likuiditas, dan $\left(\mathrm{X}_{3}\right)$ pertumbuhan produk domestik bruto (PDB).Variabel terikat yang berkaitan dengan masalah yang akan diteliti adalah variabel (Y)pertumbuhan simpanan mudharabah.

Tingkat Bagi Hasil adalah pembagian atas hasil usaha yang telah dilakukan oleh pihak-pihak yang melakukan perjanjian yaitu pihak nasabah dan pihak bank syariah (Ismail, 2011). Dihitung dengan, tingkat nisbah tabungan mudharabah ditambah dengan nisbah deposito mudharbah dibagi 2 (dua).

Likuiditas adalah masalah yang berhubungan dengan masalah kemampuan suatu perusahaan untuk memenuhi kewajiban financial-nya yang segera harus dipenuhi (Bambang Riyanto, 2008). Dihitung berdasarkan:

$$
\begin{aligned}
& \text { Cash Ratio } \\
& =\frac{\text { Kas }+ \text { Setara Kas }}{\text { Kewajiban Lancar }} \times 100 \%
\end{aligned}
$$

Produk Domestik Bruto (PDB) adalah ukuran produksi barang dan jasa total suatu negara (Eduardus, 2010). Dilihat jumlah produk domestik bruto atas dasar harga berlaku.

Mudharabah adalah akad kerjasama usaha antara 2 (dua) pihak, dimana pihak pertama bertindak sebagai pemilik dana (shaibul mal) yang menyediakan seluruh modal (100\%), sedangkan pihak lainnya sebagai pengelola usaha (mudharib) (Dimyauddin Djuwaini, 2008). Dihitung 
19AL-URBAN: Jurnal Ekonomi Syariah dan Filantropi Islam

Vol. 1, No. 1, Juni 2017

http://journal.uhamka.ac.id/index.php/al-urban

p-ISSN: 2580-3360 e-ISSN: 2581-2874

DOI: $10.22236 /$ alurban_vol1/is1pp15-26

Hal 15-25

berdasarkan jumlah deposito mudharabah

ditambah dengan tabungan mudharabah.

buku pendukung dan sumber lainnya yang

Populasi dalam penelitian ini adalah Bank

berhubungan dengan variabel yang

Umum Syariah di Indonesia yang diujikan dalam penelitian ini. Adapun

berjumlah 12 Bank Umum Syariah. jenis laporan keuangan dan data lain yang

Berikut ini adalah pertimbangan-

digunakan untuk melakukan pengumpulan pertimbangan yang digunakan dalam penentuan sampel penelitian ini meliputi:

Bank Syariah tersebut merupakan Bank Umum Syariah (BUS).

Bank Syariah tersebut sudah berdiri selama 8 tahun. Bank Syariah yang memiliki pertumbuhan relatif meningkat.

Berdasarkan kriteria yang telah ditentukan, maka diperoleh jumlah sampel sebanyak 3 (tiga) bank umum syariah dengan jumlah tahun penelitian sebanyak 5 (lima) tahun periode triwulan, diperoleh jumlah observasi dalam penelitian ini sebanyak 60 data.

Penelitian ini dilakukan pada bank umum syariah. Data diambil melalui situs www.bi.go.id dan data bps.go.id.

Teknik pengumpulan data yang digunakan dalam penelitian ini adalah metode telaah dokumen, yaitu teknik pengambilan data dengan cara mengumpulkan, mencatat dan mengkaji data sekunder yang berupa laporan keuangan bank umum syariah yang dipublikasikan oleh BI (Bank Indonesia 2012-2016. Serta dari berbagai data dalam penelitian ini adalah:

Laporan triwulan bank umum syariah yang dipublikasikan di Bank Indonesia (BI) tahun 2012-2016.

Laporan posisi keuangan bank umum syariah yang dipublikasikan di Bank Indonesia (BI) tahun 2012-2016.

Laporan distribusi bagi hasil bank umum syariah yang dipublikasikan di Bank Indonesia (BI) tahun 2012-2016.

Catatan atas keuangan bank umum syariah yang dipublikasikan di Bank Indonesia (BI) tahun 2012-2016.

Laporan triwulan Produk Domestik Bruto (PDB) yang dipublikasikan di Badan Pusat Statistik (BPS) tahun 20122016.

Pengolahan data pada penelitian ini dilakukan dengan memasukkan data ke dalam Microsoft Office Excel untuk melakukan perhitungan berdasarkan model penelitian yang digunakan. Kemudian, data yang telah terkumpul akan diolah dengan bantuan komputer menggunakan program software statistik yaitu Software Program Service Solution 
(SPSS) for windows versi 20.0. Adapun analisis data yang digunakan dalam penelitian ini yaitu analisis akuntansi, analisis regresi linear berganda, uji asumsi klasik (uji normalitas, uji multikolienaritas, uji heteroskedastisitas, dan uji autokorelasi), analisis koefisien determinasi, dan uji hipotesis.

Analisis regresi digunakan untuk mengukur seberapa besar hubungan antara variabel independen dengan variabel dependen.

Model Regresi

$\mathrm{Y}=\mathrm{a}+\mathrm{b}_{1} \mathrm{X}_{1}+\mathrm{b}_{2} \mathrm{X}_{2}+\mathrm{b}_{3} \mathrm{X}_{3}+\mathrm{e}$

Dimana:

$\mathrm{Y}=$ Pertumbuhan Simpanan

Mudharabah

$$
\begin{array}{ll}
\mathrm{a} & =\text { Konstanta } \\
\mathrm{b}_{1} & =\text { Slope } \\
\mathrm{b}_{2} & =\text { Koefisien regresi } \\
\mathrm{b}_{3} & =\text { Intersep } \\
\mathrm{X}_{1} & =\text { Pertumbuhan Tingkat Bagi Hasil } \\
\mathrm{X}_{2} & =\text { Pertumbuhan Likuiditas } \\
\mathrm{X}_{3} & =\text { Pertumbuhan Produk Domestik } \\
\text { Bruto } & \text { (PDB) } \\
\mathrm{e} & =\text { Error }
\end{array}
$$

Uji Asumsi Klasik

Uji Normalitas

Bertujuan menguji dalam model regresi kesalahan pengganggu atau residual memiliki distribusi normal atau tidak.
Uji Multikolinearitas

Bertujuan untuk menguji pada model regresi ditemukan ada atau tidak korelasi antar variabel bebas.

Uji Heteroskedastisitas

Alat untuk menguji keseragaman perpencaran varians residu tersebut.

Uji Autokorelasi

Bertujuan untuk menguji dalam model regresi linear ada atau tidak korelasi antara kesalahan pengganggu pada periode $\mathrm{t}$ dengan kesalahan pengganggu pada periode $\mathrm{t}-1$.

Analisis Koefisien Determinasi $\left(\mathrm{R}^{2}\right)$

Mengukur kemampuan model dalam menerangkan variasi variabel independen.

Uji Hipotesis

Uji Statistik t

Menunjukkan signifikan atau tidak pengaruh 1 (satu) variabel independen secara individual terhadap variabel dependen.

Uji Statistik F

meguji signifikan atau tidak pengaruh variabel independen secara simultan terhadap variabel dependen.

\section{HASIL DAN PEMBAHASAN}

Model regresi linear berganda dapat dibentuk dengan melihat pada nilai estimasi parameter dalam tabel Variables Coefficients. Estimasi parameter dari 
21AL-URBAN: Jurnal Ekonomi Syariah dan Filantropi Islam

Vol. 1, No. 1, Juni 2017

http://journal.uhamka.ac.id/index.php/al-urban

p-ISSN: 2580-3360 e-ISSN: 2581-2874

DOI: $10.22236 /$ alurban_vol1/is1pp15-26

Hal 15-25

model dan tingkat signifikansinya dapat

dilihat dari tabel berikut ini :

\begin{tabular}{|c|c|c|c|c|c|c|c|}
\hline \multirow[t]{2}{*}{ Model } & \multicolumn{2}{|c|}{$\begin{array}{l}\text { Unstandardized } \\
\text { Coefficients }\end{array}$} & \multirow{2}{*}{$\begin{array}{c}\text { Standardized } \\
\text { Coefficients } \\
\text { Beta } \\
\end{array}$} & \multirow[t]{2}{*}{$\mathrm{t}$} & \multirow[t]{2}{*}{ Sig. } & \multicolumn{2}{|c|}{$\begin{array}{c}\text { Collineanity } \\
\text { Statistics }\end{array}$} \\
\hline & B & Std. Eror & & & & Tolerance & VIF \\
\hline (Constant) & -21.194 & 7.171 & & -2.956 & .005 & & \\
\hline LOG X1 & 4.672 & 1.243 & .465 & 3.758 & .000 & .856 & 1.168 \\
\hline LOG $\mathrm{X} 2$ & .284 & .185 & .260 & 1.538 & .130 & .458 & 2.185 \\
\hline LOG X3 & 3.237 & .958 & .596 & 3.380 & .001 & .421 & 23 \\
\hline
\end{tabular}

$\log \hat{Y}=-21,194+4,672 \log X_{1}+0,284 \log X_{2}+3,237 \log X_{3}$

Koefisien regresi pertumbuhan tingkat bagi hasil $\left(\mathrm{X}_{1}\right)$ bernilai positif sebesar 4,672, artinya jika variabel pertumbuhan likuiditas $\left(\mathrm{X}_{2}\right)$ dan pertumbuhan produk domestik bruto (PDB) $\left(\mathrm{X}_{3}\right)$ tetap, sedangkan variabel pertumbuhan tingkat bagi hasil $\left(\mathrm{X}_{1}\right)$ mengalami peningkatan 0\%, maka pertumbuhan simpanan mudharabah (Y) mengalami peningkatan sebesar 4,672\%, dan sebaliknya.

Koefisien regresi pertumbuhan likuiditas $\left(\mathrm{X}_{2}\right)$ bernilai positif sebesar 0,284 , artinya jika variabel pertumbuhan tingkat bagi hasil $\left(\mathrm{X}_{1}\right)$ dan produk domestik bruto (PDB) $\left(\mathrm{X}_{3}\right)$ tetap, sedangkan variabel pertumbuhan likuiditas $\left(\mathrm{X}_{2}\right)$ mengalami peningkatan $0 \%$, maka pertumbuhan simpanan mudharabah (Y)mengalami peningkatan sebesar 0,284, dan sebaliknya.

Koefisien regresi pertumbuhan produk domestik bruto (PDB) $\left(\mathrm{X}_{3}\right)$ bernilai positif sebesar 3,237, artinya jika variabel pertumbuhan tingkat bagi hasil $\left(\mathrm{X}_{1}\right)$ dan pertumbuhan likuiditas $\left(\mathrm{X}_{2}\right)$ tetap sedangkan variabel pertumbuhan produk domestik bruto (PDB) $\left(\mathrm{X}_{3}\right)$ mengalami peningkatan $0 \%$, maka pertumbuhan simpanan mudharabah (Y)mengalami peningkatan sebesar 3,237\%, dan sebaliknya.

Pengujian asumsi klasik diperlukan sebelum pengujian hipotesis yang terdapat beberapa asumsi yang harus dipenuhi agar kesimpulan dari regresi tidak bias. Berikut ini hasil pengujian asumsi klasik:

Uji Normalitas

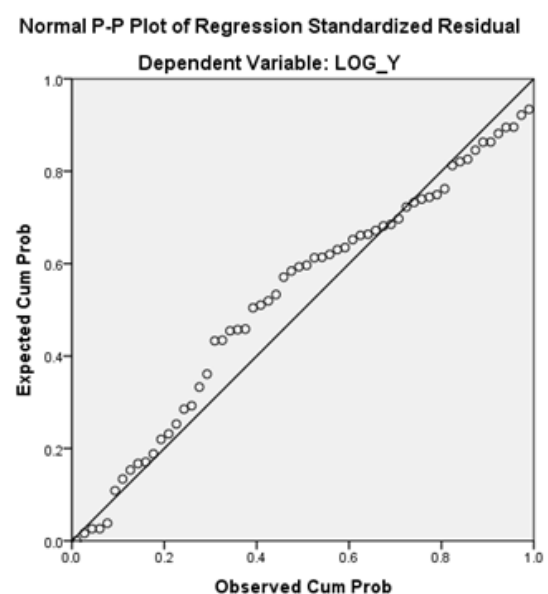

Berdasarkan gambar di atas, menunjukkan bahwa dari grafik normal probability plot terlihat titik-titik menyebar di sekitar garis diagonal serta penyebarannya mengikuti arus garis diagonal. Hal ini menunjukkan bahwa model regresi memenuhi asumsi normalitas yang berarti kesalahan pengganggu berdistribusi normal. 
Berdasarkan hasil pengujian pada tabel, tingkat signifikansinya dari uji normalitas sebesar $0,253>0,05$, maka dapat diinterpretasikan nilai residual terdistribusi normal atau memenuhi syarat uji normalitas.

\section{Uji Multikolinearitas}

Pengujian ini dilakukan dengan menghitung nilai tolerance dan Variance Inflation Factor (VIF). Jika nilai Variance Inflation Factor (VIF) tidak lebihdari 10 (VIF < 10) dan nilai tolerance tidak kurang dari 0,10 (10\%), maka dapat dikatakan terbebas dari multikolinearitas. Berdasarkan tabel hasil pengujian, diketahui bahwa nilai VIF pada pertumbuhan tingkat bagi hasil sebesar 1,168, pertumbuhan likuiditas 2,185, dan pertumbuhan produk domestik bruto sebesar 2,373 yang berarti tidak ada yang melebihi angka 10 (VIF < 10). Kemudian nilai tolerance pertumbuhan tingkat bagi hasil sebesar 0,856, pertumbuhan likuiditas 0,458 , dan pertumbuhan produk domestik bruto sebesar sebesar 0,421 yang berarti tidak ada yang kurang dari 0,10 (tolerance $>$ 0,10). Maka dapat disimpulkan bahwa model regresi pada penelitian ini tidak terjadi multikolinearitas.

Uji Heteroskedastisitas
Dari gambar di bawah ini, menunjukkan bahwa grafik scatterplot terlihat tidak ada pola tertentu yang jelas dan titik-titik menyebar di atas dan di bawah angka 0 (nol) pada sumbu Y. Hal ini dapat disimpulkan bahwa tidak terjadi heteroskedastisitas pada model regresi terjadi ketidaksamaan varians dari residual satu pengamatan ke pengamatan yang lain. Sehingga model regresi layak dipakai untuk memprediksi masalah penelitian.

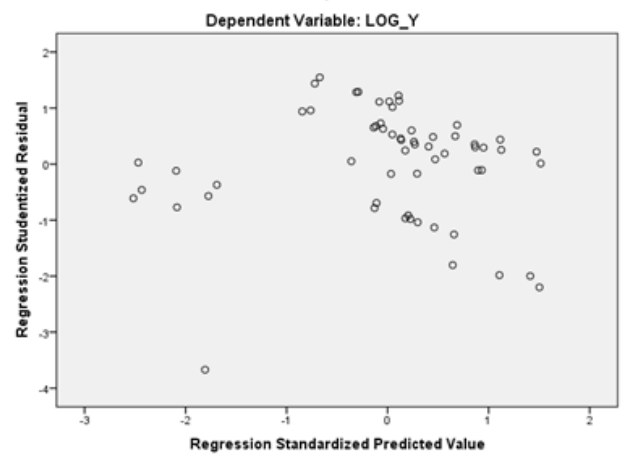

Uji Autokorelasi

Metode pengujian menggunakan uji Durbin-Watson (uji DW). Nilai Durbin Watson dapat dilihat melalui output tabel model summary di bawah ini :

\begin{tabular}{|l|r|r|r|r|r|}
\hline Model & \multicolumn{1}{|c|}{$\mathrm{R}$} & $\mathrm{R}$ Square & $\begin{array}{c}\text { Adjusted } R \\
\text { Square }\end{array}$ & $\begin{array}{c}\text { Std. Error of the } \\
\text { Estimate }\end{array}$ & Durbin-Watson \\
\hline 1 & $.515^{\mathrm{3}}$ & .265 & .226 & .28243 & .381 \\
\hline
\end{tabular}

Nilai Durbin-Watson dari hasil pengujian 0,381. Dari jumlah data $(\mathrm{n})=60$ dan $\mathrm{K}=$ 3 (merupakan jumlah variabel independen) diperoleh nilai $\mathrm{dL}$ sebesar 1,464 dan nilai dU sebesar 1,685. Nilai Durbin-Watson sebesar 0,381 terletak 
23AL-URBAN: Jurnal Ekonomi Syariah dan Filantropi Islam

Vol. 1, No. 1, Juni 2017

http://journal.uhamka.ac.id/index.php/al-urban

p-ISSN: 2580-3360 e-ISSN: 2581-2874

DOI: $10.22236 /$ alurban_vol1/is1pp15-26

Hal 15-25

pada daerah 4-dL > d < dU (2,315 > 0,381

$<1,685)$, maka dapat diinterpretasi bahwa

terdapat autokorelasi pada model regresi.

dependen (pertumbuhan simpanan mudharabah).

Dalam pengujian Runs Test apabila angka signifikasi $<0,05$ maka terjadi autokorelasi. Dalam pengujian Runs Test ini menghasilkan angka signifikasi sebesar 0,000 sehingga dapat dikatakan bahwa terjadi autokorelasi.

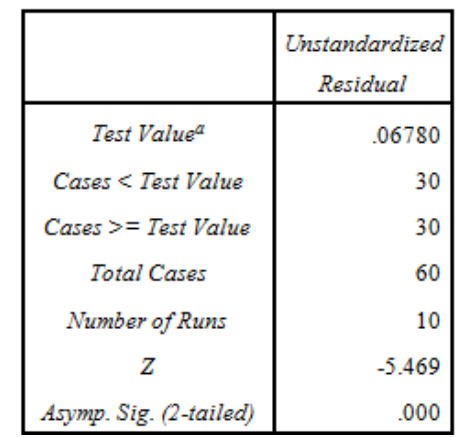

Berdasarkan hasil uji asumsi klasik yaitu uji normalitas menunjukkan residual berdistribusi normal, uji multikolinearitas menunjukkan tidak terjadi multikolinearitas, uji heteroskedastisitas menunjukkan tidak terjadi heteroskedastisitas, dan uji autokorelasi menunjukkan terjadi autokorelasi, maka model regresi yang diperoleh tidak memenuhi persyaratan BLUE (Best Linear Unbiased Estimator) yang berarti variabel independen (pertumbuhan tingkat bagi hasil, pertumbuhan likuiditas, dan pertumbuhan produk domestik bruto) tidak dapat menjadi prediksi variabel Adjusted $R$ Square sebesar 0,265, hal ini

Berdasarkan tabel pengujian, nilai berarti variabel pertumbuhan tingkat bagi hasil, pertumbuhan likuiditas, dan pertumbuhan produk domestik bruto (PDB), terhadap pertumbuhan simpanan mudharbah sebesar 26,5\%, sedangkan sisanya 73,5\% (100\% - 26,5\%) dijelaskan oleh variabel lain yang tidak dimasukkan dalam penelitian ini seperti Financing to Deposit Ratio, Return On Asset, Kurs, Jumlah Uang Beredar, BI rate, dan lainnya.

Hasil pengujian hipotesis t mengenai pengaruhpertumbuhan tingkat bagi hasil terhadap pertumbuhan simpanan mudharabahmenunjukkan nilai $t_{\text {hitung }}$ sebesar 3,758 > t $(0,05 / 2 ; 56)=2,003$ dan signifikansi sebesar $0,000<0,05$, maka dapat diinterpretasikan $\mathrm{H}_{1}$ diterima yang menunjukkan terdapat pengaruh parsial yang signifikan antara pertumbuhan tingkat bagi hasilterhadap pertumbuhan simpanan mudharabah.

Hasil pengujian hipotesis $t$ mengenai pengaruh pertumbuhan likuiditas terhadap pertumbuhan simpanan mudharabah menunjukkan nilai $\mathrm{t}_{\text {hitung }}$ sebesar 1,538<t $(0,05 / 2 ; 56)=2,003$ dan signifikansi 
sebesar $0,130>0,05$, maka dapat tingkat bagi hasil sebesar -14,85, diinterpretasikan $\mathrm{H}_{2}$ ditolak yang pertumbuhan likuiditas -87,09, menunjukkan tidak terdapat pengaruh pertumbuhan produk domestik bruto parsial dan tidak signifikan antara 2,47, dan pertumbuhan simpanan pertumbuhan likuiditas terhadap mudharabah sebesar -87,74. Nilai pertumbuhan simpanan mudharabah.

Hasil pengujian hipotesis t mengenai pengaruh pertumbuhan produk domestik bruto terhadap pertumbuhan simpanan mudharabah menunjukkan nilai $t_{\text {hitung }}$ sebesar 3,380 $>\mathrm{t}(0,05 / 2 ; 56)=2,003$ dan signifikansi sebesar $0,001<0,05$, maka dapat diinterpretasikan $\mathrm{H}_{3}$ diterima yang menunjukkanterdapat pengaruh parsial yangsignifikan antara pertumbuhan produk domestik brutoterhadap pertumbuhan simpanan mudharabah.

Hasil pengujian hipotesis F (simultan) bahwa nilai $\mathrm{F}_{\text {hitung }}=6,733>\mathrm{F}_{0,05}(3 ; 56)=$ 2,77 dan tingkat signifikansi sebesar 0,001 $<$ 0,05, dengan demikian bahwa ke-3 (tiga) variabel yaitu pertumbuhan tingkat bagi hasil, pertumbuhan likuiditas, dan pertumbuhan produk domestik bruto secara bersama-sama berpengaruh signifikan dan positif terhadap pertumbuhan simpanan mudharabah.

\section{SIMPULAN}

Berdasarkan atas hasil pengolahan data dan analisis akuntansi, maka diperoleh hasil nilai minimum variabel pertumbuhan maximum variabel pertumbuhan tingkat bagi hasil sebesar 19,35, pertumbuhan likuiditas 64,43, pertumbuhan produk domestik bruto 6,34, dan pertumbuhan simpanan mudharabah sebesar 689,50. Nilai mean variabel pertumbuhan tingkat bagi hasil sebesar -6,53, pertumbuhan likuiditas -341,62, pertumbuhan produk domestik bruto 1,92, dan pertumbuhan simpanan mudharabah sebesar 24,00.

Dari analisis regresi linear berganda diperoleh model regresi linear berganda $\log \hat{Y}=-21,194+4,672 \log X_{1}+$ $0,284 \log X_{2}+3,237 \log X_{3}$ yang telah diuji asumsi klasik yaitu uji normalitas residual berdistribusi normal, tidak terjadi multikolinearitas, tidak terjadi heterokedastisitas, dan terjadi autokorelasi maka model regresi tidak memenuhi persyaratan BLUE (Best Linear Unbiased Estimator), yang berarti variabel independen (pertumbuhan tingkat bagi hasil, pertumbuhan likuiditas, dan pertumbuhan produk domestik bruto) tidak dapat menjadi prediksi variabel dependen (pertumbuhan simpanan 
25AL-URBAN: Jurnal Ekonomi Syariah dan Filantropi Islam

Vol. 1, No. 1, Juni 2017

http://journal.uhamka.ac.id/index.php/al-urban

p-ISSN: 2580-3360 e-ISSN: 2581-2874

DOI: $10.22236 /$ alurban_vol1/is1pp15-26

Hal 15-25

mudharabah).

mudharabah dengan nilai $t_{\text {hitung }}$ sebesar

Besarnya nilai Adjusted $R$ Square $3,380>\mathrm{t}(0,05 / 2 ; 56)=2,003$ dan sebesar 0,265 artinya 26,5\% variabel pertumbuhan simpanan mudharabah signifikansi sebesar $0,001<0,05$. Hasil uji dapat dijelaskan oleh variabel hipotesis secara simultan (uji f), antara pertumbuhan tingkat bagi hasil, pertumbuhan tingkat bagi hasil, pertumbuhan likuiditas, dan pertumbuhan produk domestik bruto (PDB) sedangkan sisanya 73,5\% (100\% - 26,5\%) dijelaskan oleh variabel lain yang tidak dimasukkan dalam penelitian ini Financing to Deposit Ratio, Return On Asset, Kurs, Jumlah Uang Beredar, BI rate, dan lainnya

Hasil pengujian hipotesis parsial (uji t), menunjukkan bahwa pertumbuhan tingkat bagi hasil berpengaruh signifikan dan positif terhadap pertumbuhan simpanan mudharabah dengan nilai $\mathrm{t}_{\text {hitung }}$ sebesar $3,758>\mathrm{t}(0,05 / 2 ; 56)=2,003$ dan signifikansi sebesar $0,000<0,05$. Hasil pengujian pertumbuhan likuiditas secara parsial berpengaruh negatif tidak signifikan terhadap pertumbuhan simpanan mudharabah dengan nilai $t_{\text {hitung }}$ sebesar $1,538<\mathrm{t}(0,05 / 2 ; 56)=2,003$ dan signifikansi sebesar 0,130>0,05. Dan hasil pertumbuhan produk domestik bruto secara parsial berpengaruh signifikan dan positif terhadap pertumbuhan simpanan produk domestik bruto (PDB) berpengaruh signifikan dan positif terhadap pertumbuhan simpanan mudharabah, hal ini terlihat dari hasil uji $\mathrm{F}$ di mana $\mathrm{F}_{\text {hitung }}=6,733>\mathrm{F}_{0,05}(3 ; 56)=$ 2,77 dan tingkat signifikansi sebesar 0,001 $<0,05$

\section{REFERENSI}

Bambang Riyanto. (2010). Dasar Dasar Pembelanjaan Perusahaan. Yogyakarta: BPFE

Dimyauddin Djuwaini. (2008). Pengantar Fiqh Muamalah. Yogyakarta: Pustaka Pelajar.

Ismail. (2011). Perbankan Syariah. Jakarta: Kencana.

Khaerul umam. (2013). Manajemen Perbankan Syariah, Cetakan Satu. Bandung : Pustaka Setia.

Tendelilin, Eduardus. (2010). Portofolio dan Investasi. Kanisius: Jakarta

www.bi.go.id 